\title{
HARGA SAHAM SYARIAH DITINJAU DARI RASIO PROFITABILITAS
}

\author{
Indah Dewi Maharany', Luthfiyatun Ni'mah'2 \\ 1,2Institut Agama Islam Negeri Kudus, Kudus \\ $\bowtie$ 1indahdewi.edu@gmail.com, 2luthfiyatun78@gmail.com
}

\begin{abstract}
The results showed that EPS has a significant positive effect on Islamic stock prices. Based on the value of t count greater than t table (3.556>1.67591), and based on the value of the significance coefficient of 0.001 which is smaller than 0.05. Dividend Per Share (DPS) has a significant positive effect on Islamic stock prices. Based on the value of t count greater than $t$ table (1.833>1.67591), and based on the value of the significance coefficient of 0.033 which is smaller than 0.05. Return On Assets (ROA) has a significant positive effect on Islamic stock prices. Based on the value of t count greater than t table (2.833>1.67591), and based on the value of the significance coefficient of 0.049 which is smaller than 0.05. Return On Equity (ROE) has no effect on Islamic stock prices. Based on the t count value is smaller than $t$ table $(0.612<1.67591)$, and based on the significance coefficient value of 0.543 which is greater than 0.05 .

Keywords : Earning Per Share (EPS), Dividend Per Share (DPS), Return On Assets (ROA), Return On Equity (ROE), Sharia Stock Prices.
\end{abstract}

\section{LATAR BELAKANG}

Pasar modal telah menjadi bagian yang sangat penting untuk mendorong pertumbuhan perekonomian negara Indonesia (Haq, Sari, \& Hana, 2020). Hal tersebut dapat dilihat dari besarnya kontribusi pasar modal Indonesia terhadap pertumbuhan perekonomian nasional. Menurut Menteri Koordinator Bidang Perekonomian, Airlangga Hartarto, menjelaskan bahwa pada tahun 2018 kontribusi pasar modal terhadap pertumbuhan ekonomi Indonesia yang diukur melalui Produk Domestik Bruto (PDB) mencapai angka 47\%, dengan nilai kapitalisasi pasar sebesar Rp 6.920 triliun. Meskipun demikian, nilai kontribusi pasar modal Indonesia terhadap pertumbuhan perekonomian nasional dikatakan masih kecil. Hal ini dikarenakan, nilai kontribusinya masih rendah apabila dibandingkan dengan beberapa negara di Asia lainnya. Adapun negara-negara di Asia tersebut seperti, Vietnam dengan kontribusi pasar modal mencapai 52\% terhadap PDB, Thailand dengan kontribusi pasar modal mencapai 98\% terhadap PDB, Malaysia dengan kontribusi pasar modal mencapai 113\% terhadap PDB, dan Singapura dengan kontribusi pasar modal mencapai 189\% terhadap PDB (Anggraeni, 2019).

Berdasarkan data perusahaan yang terdaftar di Jakarta Islamic Index (JII) periode 2015-2019, dapat ditemukan suatu fenomena gap atau teori tidak sejalan dengan 
fenomena yang ada. Adapun fenomena gap tersebut dapat dilihat pada tabel di bawah ini:

Tabel 1 Rata-rata EPS, DPS, ROA, ROE dan Harga Saham pada Perusahaan yang Terdaftar di Jakarta Islamic Index (JII) Periode 2015-2019

\begin{tabular}{c|c|c|c|c|c}
\hline Tahun & EPS (Rp) & DPS (Rp) & ROA (\%) & ROE (\%) & $\begin{array}{c}\text { Harga Saham } \\
\text { (Rp) }\end{array}$ \\
\hline 2015 & 394 & 251,80 & 14 & 38 & 10392,27 \\
\hline 2016 & 436,18 & 252,25 & 14 & 35 & 10692,27 \\
\hline 2017 & 653,91 & 301,44 & 7 & 19 & 10964,09 \\
\hline 2018 & 690,77 & 350,90 & 12 & 23 & 10681,36 \\
\hline 2019 & 619,98 & 170,28 & 10 & 23 & 9713,64
\end{tabular}

Sumber : www.idx.co.id, 2021

Berdasarkan tabel di atas, dapat diketahui terdapat fenomena gap pada perusahaan yang terdaftar di Jakarta Islamic Index (JII) periode 2015 sampai 2019. Rata-rata indikator Earning Per Share (EPS) pada perusahaan yang terdaftar di Jakarta Islamic Index (JII) tahun 2016 terjadi peningkatan 42,18 dari 394 menjadi 436,18. Pada tahun 2017 Earning Per Share (EPS) terjadi peningkatan 217,73 dari 436,18 menjadi 653,91. Tahun 2018 Earning Per Share (EPS) juga terjadi peningkatan 36,86 dari 653,91 menjadi 690,77. Tahun 2019 Earning Per Share (EPS) terjadi penurunan 70,79 dari 690,77 menjadi 619,98. Fenomena gap yang terdapat pada variabel Earning Per Share (EPS) yaitu terjadi pada tahun 2018. Pada tahun 2018 Earning Per Share (EPS) terjadi peningkatan, namun hal tersebut tidak menyebabkan harga saham terjadi peningkatan pula, akan tetapi harga saham justru menurun. Fenomena tersebut tidak sejalan dengan teori yang ada yaitu semakin tinggi nilai Earning Per Share (EPS) suatu perusahaan, maka hal tersebut akan menjadikan daya tarik para investor untuk menyertakan aset yang dimilikinya pada saham perusahaan tersebut. Oleh sebab itu harga saham juga akan mengalami peningkatan, begitu pula sebaliknya.

\section{TEORI DAN METODE}

\subsection{Harga Saham Syariah}

Harga dari tiap lembar saham yang berlaku di pasar modal disebut dengan harga saham (Hana, 2018). Harga saham menjadi faktor yang sangat penting untuk meningkatkan keyakinan para investor dalam melakukan investasi (Rini, Farrukhy, \& Hana, 2020). Hal tersebut dikarenakan harga saham menunjukkan prestasi suatu emiten. Ada tiga kategori harga saham di pasar modal, antara lain harga tertinggi (highest price), harga terendah (lowest price), dan harga penutupan (closing price) (Egam, Ilat, \& Pangerapan, 2017).

\subsection{Earning Per Share (EPS)}

Earning Per Share (EPS) atau laba per saham merupakan salah satu jenis rasio profitabilitas yang digunakan untuk memperlihatkan seberapa besar keuntungan yang diperoleh para pemegang saham tiap lembar saham yang beredar. Artinya, rasio ini memperlihatkan jumlah rupiah yang didapatkan oleh para pemegang saham untuk 
setiap lembar saham yang dimilikinya (Syamsuddin, 2011). Earning Per Share (EPS) juga menunjukkan kinerja perusahaan dalam hal pencapaian keuntungan untuk per lembar sahamnya. Oleh sebab itu, para investor mampu mengukur berapa laba yang akan diperolehnya dengan cara melihat EPS suatu perusahaan. Earning Per Share dapat dihitung dengan menggunakan rumus (Filbert \& Prasetya, 2020):

$$
\text { EPS }=\frac{\text { Laba yang Didistribusikan kepada Pemilik Perusahaan }}{\text { Rata }- \text { rata Tertimbang Saham yang Beredar }}
$$

Jadi, Earning Per Share (EPS) ini dapat dikatakan sebagai indikator yang mempengaruhi harga saham. Hal tersebut dikarenakan para investor menaruh perhatian pada laba perusahaan, karena dari laba itulah dapat mencerminkan keadaan suatu perusahaan. Oleh sebab itu, apabila nilai Earning Per Share semakin besar maka semakin baik pula kinerja keuangan suatu perusahaan.

\subsection{Dividend Per Share (DPS)}

Dividend Per Share (DPS) merupakan nilai dividen yang dibagikan kepada setiap pemegang saham untuk setiap lembar saham yang dimilikinya. Artinya, rasio ini menjelaskan tentang jumlah keuntungan yang akan diberikan kepada pemegang saham dalam bentuk dividen tunai untuk per lembar saham yang dimilikinya. Nilai dividen itu sendiri berdasarkan atas persentase laba bersih yang dimiliki perusahaan. Dividend Per Share (DPS) dapat dihitung dengan menggunakan rumus (Rahardjo, 2006):

$$
\text { DPS }=\frac{\text { Total Nilai Dividen }}{\text { Jumlah Saham Beredar }}
$$

Semakin besar nilai Dividend Per Share, maka memperlihatkan bahwa kinerja perusahaan dalam keadaan baik serta perusahaan dapat mewujudkan kebutuhan para investor dalam bentuk dividen. Hal ini menyebabkan permintaan atas saham perusahaan tersebut menjadi meningkat, sehingga harga saham juga akan naik. Jadi, hal tersebut sesuai dengan signalling theory atau teori sinyal yaitu investor mendapatkan sinyal baik dari perusahaan (Tejaningtyas, 2016).

\subsection{Return On Asset (ROA)}

Return On Assets (ROA) merupakan salah satu jenis rasio profitabilitas yang digunakan untuk mengukur seberapa besar laba bersih yang didapat oleh perusahaan dari aset yang dimilikinya. Artinya, ROA ini merupakan rasio yang bertujuan untuk menilai kinerja suatu perusahaan dalam mendapatkan laba secara keseluruhan. Pada dasarnya, setelah mengetahui nilai Return On Assets, maka para investor dapat mengamati bagaimana kemungkinan perkembangan perusahaan tersebut (Saputro, 2019). Jadi, semakin besar rasio ini, maka semakin besar juga perolehan keuntungan yang diraih oleh perusahaan, sehingga semakin baik juga kondisi perusahaan dari aspek pemakaian aset. Sebaliknya, semakin kecil rasio ini, maka semakin kecil juga perolehan keuntungan yang diraih oleh perusahaan, sehingga semakin tidak baik (Ramdhani, 2013). Return On Assets dapat dihitung dengan menggunakan rumus (Husnan, 2015): 


$$
\text { ROA }=\frac{\text { Laba Setelah Pajak }}{\text { Total Aset }}
$$

Jadi, Return On Assets (ROA) ini dapat dikatakan sebagai indikator yang mempengaruhi harga saham. Hal tersebut dikarenakan jika nilai Return On Assets naik, maka perusahaan tersebut dikatakan mampu untuk memanfaatkan aset yang dimilikinya secara produktif. Artinya, perusahaan mampu menghasilkan keuntungan yang besar. Hal ini akan menarik minat para investor untuk membeli saham perusahaan tersebut atau membuat permintaan atas saham perusahaan menjadi meningkat, sehingga pada akhirnya harga saham juga akan naik. Jadi, hal tersebut sesuai dengan signalling theory atau teori sinyal yaitu investor mendapatkan sinyal baik dari perusahaan (Cahyaningrum \& Antikasari, 2017).

\subsection{Return On Equity (ROE)}

Return On Equity (ROE) merupakan salah satu jenis rasio profitabilitas yang digunakan untuk mengukur kemampuan suatu perusahaan mengenai seberapa besar laba bersih yang dihasilkan dari penggunaan ekuitas yang dimilikinya. Artinya, nilai Return On Equity ini memperlihatkan keefisienan perusahaan dalam menggunakan modal sendiri. Apabila rasio ini semakin tinggi, berarti semakin baik, karena kedudukan pemilik perusahaan juga semakin kuat (Kasmir, 2016). Jadi, dengan melihat nilai Return On Equity para pemegang saham dapat mengetahui tingkat pengembalian atas saham yang mereka punya. Return On Equity dapat dihitung dengan menggunakan rumus (Sukamulja, 2019):

$$
\text { ROE }=\frac{\text { Laba Setelah Pajak }}{\text { Total Ekuitas }}
$$

Jadi, Return On Equity (ROE) ini dapat dikatakan sebagai indikator yang mempengaruhi harga saham. Hal tersebut dikarenakan jika nilai Return On Equity naik, maka perusahaan tersebut dikatakan mampu untuk memperlihatkan keefisienan dalam menggunakan modal sendiri. Artinya, dengan nilai Return On Equity yang naik, maka akan menarik minat para investor untuk membeli saham perusahaan tersebut atau membuat permintaan atas saham perusahaan menjadi meningkat, sehingga pada akhirnya harga saham juga akan naik. Jadi, hal tersebut sesuai dengan signalling theory atau teori sinyal yaitu investor mendapatkan sinyal baik dari perusahaan (Cahyaningrum \& Antikasari, 2017).

\subsection{Metode Penelitian}

Jenis penelitian ini adalah penelitian field research dengan menggunakan metode dokumentasi yaitu penelitian yang menggunakan teknik pengumpulan data dokumentasi yang berasal dari website resmi Bursa Efek Indonesia yaitu www.idx.co.id. Sampel merupakan bagian yang berasal dari jumlah serta keunikan yang dimiliki oleh suatu populasi (Sugiyono, 2014). Adapun teknik pengambilan sampel yang digunakan, yaitu purposive sampling. Purposive sampling merupakan metode untuk menentukan sampel melalui beberapa kriteria tertentu (Sugiyono, 2014). Adapun kriteria yang wajib dipenuhi oleh sampel yang akan dipakai dalam penelitian ini antara lain perusahaan yang tergabung di Jakarta Islamic Index (JII), perusahaan yang sahamnya konsisten masuk dalam penghitungan Jakarta Islamic 
Index selama periode pengamatan, yaitu mulai tahun 2015 sampai 2019, perusahaan yang memakai satuan rupiah pada laporan keuangannya, dan perusahaan yang memberikan dividen tunai selama periode 2015 sampai 2019. Berdasarkan kriteria di atas, maka total sampel penelitian ini berjumlah 11 perusahaan.

\section{HASIL DAN PEMBAHASAN}

\subsection{Hasil Analisis Data}

Tabel 2 Statistik Deskriptif

\begin{tabular}{|c|c|c|c|c|c|}
\hline & EPS & DPS & ROA & ROE & $\begin{array}{l}\text { Harga Saham } \\
\text { Syariah }\end{array}$ \\
\hline \begin{tabular}{l|l}
$\mathrm{N}$ & Valid \\
\cline { 2 - 2 }
\end{tabular} & 55 & 55 & 55 & 55 & 55 \\
\hline Missing & 0 & 0 & 0 & 0 & 0 \\
\hline Mean & 558,9691 & 265,3346 & 0,1147 & 0,2742 & 8,7282 \\
\hline Median & 393,0000 & 168,0000 & 0,0697 & 0,1297 & 8,6995 \\
\hline Mode & $221,50^{a}$ & $26,00^{\mathrm{a}}$ & $0,04^{a}$ & 0,20 & $8,70^{\mathrm{a}}$ \\
\hline Minimum & 43,00 & 19,00 & 0,01 & 0,04 & 7,19 \\
\hline Maximum & 3243,00 & 1193,00 & 0,46 & 1,61 & 10,76 \\
\hline Sum & 30743,30 & 14593,40 & 6,31 & 15,08 & 480,05 \\
\hline
\end{tabular}

Dari data tersebut, diketahui bahwa Mean pada variabel Earning Per Share (EPS) pada tahun 2015-2019 adalah 558,9691, pada variabel Dividend Per Share (DPS) adalah 265,3346, pada variabel Return On Assets (ROA) adalah 0,1147, pada variabel Return On Equity (ROE) adalah 0,2742, dan pada variabel harga saham syariah adalah 8,7282. Median pada variabel Earning Per Share (EPS) pada tahun 2015-2019 adalah 393,0000, pada variabel Dividend Per Share (DPS) adalah 168,0000, pada variabel Return On Assets (ROA) adalah 0,0697, pada variabel Return On Equity (ROE) adalah 0,1297 , dan pada variabel harga saham syariah adalah 8,6995. Modus/mode pada variabel Earning Per Share (EPS) pada tahun 2015-2019 adalah 221,50a, pada variabel Dividend Per Share (DPS) adalah 26,00a, pada variabel Return On Assets (ROA) adalah 0,04a, pada variabel Return On Equity (ROE) adalah 0,20, dan pada variabel harga saham syariah adalah 8,70. Minimum atau nilai data paling kecil untuk variabel Earning Per Share (EPS) pada tahun 2015-2019 adalah 43,00, pada variabel Dividend Per Share (DPS) adalah 19,00, pada variabel Return On Assets (ROA) adalah 0,01, pada variabel Return On Equity (ROE) adalah 0,04, dan pada variabel harga saham syariah adalah 7,19. Maximum, data maksimum atau nilai data paling besar untuk variabel Earning Per Share (EPS) pada tahun 2015-2019 adalah 3243,00, pada variabel Dividend Per Share (DPS) adalah 1193,00, pada variabel Return On Assets (ROA) adalah 0,46, pada variabel Return On Equity (ROE) adalah 1,61, dan pada variabel harga saham syariah adalah 10,76 .

Tabel 3 Hasil Uji Asumsi Klasik

\begin{tabular}{|l|l|l|}
\hline Uji & Nilai & Hasil \\
\hline Normalitas & Grafik histogram menunjukkan & Data terdistribusi normal \\
& pola distribusi normal & \\
\hline Multikolinieritas & VIF X $\mathrm{X}_{1}=7,203$ & Tidak terdapat \\
& $\mathrm{X}_{2}=8,874$ & multikolinieritas dalam model \\
& $\mathrm{X}_{3}=7,312$ & penelitian \\
\hline
\end{tabular}




\begin{tabular}{|l|l|l|}
\hline & $\mathrm{X}_{4}=7,509$ & terjadi \\
\hline Heteroskedastisitas & $\begin{array}{l}\text { Titik-titik data menyebar di atas } \\
\text { dan di bawah titik nol sumbu y }\end{array}$ & $\begin{array}{l}\text { Tidak } \\
\text { heteroskedastisitas }\end{array}$ \\
\hline Autokorelasi & $\mathrm{DW}=1,783$ & Tidak terjadi autokorelasi \\
\hline
\end{tabular}

Berdasarkan tabel tersebut grafik histogram menunjukkan hasil data terdistribusi normal. Tidak terjadi gejala multikolinieritas, artinya tidak terjadi hubungan linier antara variabel bebas yang digunakan dalam model regresi. Tidak terjadi heteroskedastisitas pada model regresi, sehingga model regresi layak dipakai untuk menganalisis pengaruh Earning Per Share (EPS), Dividend Per Share (DPS), Return On Assets (ROA) dan Return On Equity (ROE) terhadap harga saham syariah perusahaan yang terdaftar di Jakarta Islamic Index Periode 2015-2019. Pada uji autokorelasi sesuai kaidah pengambilan keputusan disimpulkan bahwa tidak terdapat autokorelasi positif maupun negatif pada model regresi.

Tabel 4 Hasil Uji Analisis Regresi

\begin{tabular}{|c|c|c|}
\hline Uji & Nilai & Hasil \\
\hline Koefisien Regresi & $\begin{array}{l}\text { Konstanta }=4,892 \\
\mathrm{~b}_{1}=0,526 \\
\mathrm{~b}_{2}=0,264 \\
\mathrm{~b}_{3}=0,141 \\
\mathrm{~b}_{4}=0,103\end{array}$ & $\begin{array}{l}\text { Menunjukkan besarnya pengaruh variabel } \\
\text { X terhadap Y secara sendiri-sendiri }\end{array}$ \\
\hline $\begin{array}{l}\text { Koefisien } \\
\text { determinasi }\end{array}$ & $\mathrm{R}^{2}=0,836$ & Berpengaruh $=83,6 \%$ \\
\hline Uji F & $\mathrm{F}=70,054$ sig $=0,000$ & Berpengaruh secara berganda \\
\hline Uji t & $\begin{array}{l}t_{1}=3,556 \text { sig }=0,001 \\
t_{2}=1,833 \text { sig }=0,033 \\
t_{3}=2,833 \text { sig }=0,049 \\
t_{4}=0,612 \quad \text { sig }=0,543\end{array}$ & $\begin{array}{l}\mathrm{X}_{1} \text { berpengaruh terhadap } \mathrm{Y} \\
\mathrm{X}_{2} \text { berpengaruh terhadap } \mathrm{Y} \\
\mathrm{X}_{3} \text { berpengaruh terhadap } \mathrm{Y} \\
\mathrm{X}_{4} \text { tidak berpengaruh terhadap } \mathrm{Y}\end{array}$ \\
\hline
\end{tabular}

Berdasarkan output regresi, diperoleh nilai besaran pengaruh secara berturutturut X1, X2, X3 dan X4 sebesar 0,526; 0,264; 0,141; 0,103. Pada model Adjusted $R^{2}$ besarnya 0,836 . Ini berarti variabel harga saham syariah dapat dijelaskan oleh variabel Earning Per Share (EPS), Dividend Per Share (DPS), Return On Assets (ROA) dan Return On Equity (ROE) yang diturunkan dalam model sebesar 83,6\%. Secara bersama-sama terdapat pengaruh X1, X2, X3 dan X4 terhadap harga saham syariah perusahaan yang terdaftar di Jakarta Islamic Index Periode 2015-2019. Pada uji t, dapat dilihat bahwa X1, X2, X3, memiliki nilai thitung diatas 1,67591 dan tingkat signifikansi dibawah 0,05. Hal ini menunjukkan bahwa ada pengaruh yang signifikan secara individu antara X1, X2, X3 terhadap Y. Namun X4 memiliki nilai t hitung dibawah 1,67591 dan tingkat signifikansi diatas 0,05 . Hal ini menunjukkan bahwa tidak ada pengaruh yang signifikan secara individu antara X4 terhadap Y. 


\subsection{Pembahasan}

Dari penelitian ini dapat diketahui bahwa terdapat pengaruh Earning Per Share (EPS) terhadap harga saham syariah perusahaan yang terdaftar di Jakarta Islamic Index Periode 2015-2019. Data penelitian menunjukkan, jika Earning Per Share (EPS) sebuah perusahaan mampu melebihi angka 558,9691 maka terdapat indikasi investor untuk membeli saham tersebut. Artinya dalam setiap 1 lembar saham akan memperoleh keuntungan atau laba sebesar 558,9691. Oleh sebab itu diharapkan bagi pihak perusahaan untuk meningkatkan pembagian laba pada setiap lembar saham sehingga mampu menarik investor menanamkan modal pada perusahaan tersebut. Terdapat pengaruh Dividend Per Share (DPS) terhadap harga saham syariah perusahaan yang terdaftar di Jakarta Islamic Index Periode 2015-2019. Data penelitian menunjukkan, jika Dividend Per Share (DPS) sebuah perusahaan mampu melebihi angka 265,3346 maka terdapat indikasi investor untuk membeli saham tersebut. Artinya dalam setiap 1 lembar saham akan memperoleh dividen yaitu keuntungan yang dibagikan kepada investor setelah dikurangi untuk kebutuhan investasi perusahaan sebesar 265,3346. Oleh sebab itu diharapkan bagi pihak perusahaan untuk meningkatkan pembagian dividen pada setiap lembar saham sehingga mampu menarik investor menanamkan modal pada perusahaan tersebut. Terdapat pengaruh Return On Assets (ROA) terhadap harga saham syariah perusahaan yang terdaftar di Jakarta Islamic Index Periode 20152019. Data penelitian menunjukkan, jika Return On Assets (ROA) sebuah perusahaan mampu melebihi angka 11,47\% maka terdapat indikasi investor untuk membeli saham tersebut. Artinya perusahaan mampu menghasilkan laba bersih sebesar 11,47\% dari total aset yang dimiliki yang digunakan untuk operasional perusahaan. Oleh sebab itu diharapkan bagi pihak perusahaan untuk meningkatkan laba bersih perusahaan sehingga mampu menarik investor menanamkan modal pada perusahaan tersebut. Tidak terdapat pengaruh Return On Equity (ROE) terhadap harga saham syariah perusahaan yang terdaftar di Jakarta Islamic Index Periode 2015-2019. Hasil penelitian ini tidak mendukung hipotesis bahwa ternyata Return On Equity yang tinggi belum mampu memperlihatkan keefisienan dalam menggunakan modal sendiri. Karena investor yang akan menanamkan modalnya pada sebuah perusahaan akan terlebih dahulu melihat poin-poin utama mencapaian perusahaan tersebut yang bisa dilihat dengan laba yang diberikan pada satu lembar saham, pembagian keuntungan berupa dividen yang dibagikan pada setiap satu lembar saham. Jika nilai-nilai tersebut menunjukkan angka yang tinggi maka investor akan menanamkan dananya pada perusahaan tersebut tanpa melihat pengembalian keuntungan atas modalnya (ROE).

\section{PENUTUP}

Dari hasil penelitin ini dapat disimpulkan bahwa Earning Per Share (EPS) berpengaruh positif signifikan terhadap harga saham syariah. Dividend Per Share (DPS) berpengaruh positif signifikan terhadap harga saham syariah. Return On Assets (ROA) berpengaruh positif signifikan terhadap harga saham syariah. Return On Equity (ROE) tidak berpengaruh terhadap harga saham syariah. 


\section{DAFTAR PUSTAKA}

Anggraeni, R. (2019, December). Airlangga: Pasar Modal Indonesia Masih Menarik. Sindonews.Com.

Cahyaningrum, Y. W., \& Antikasari, T. W. (2017). Pengaruh Earning Per Share, Price To Book Value, Return on Asset, Dan Return on Equity Terhadap Harga Saham Sektor $\begin{array}{llll}\text { Keuangan. Jurnal Economia, } 1912), & \end{array}$ https://doi.org/10.21831/economia.v13i2.13961

Egam, G. E. Y., Ilat, V., \& Pangerapan, S. (2017). Pengaruh Return On Asset (ROA), Return On Equity (ROE), Net Profit Margin (NPM), dan Earning Per Share (EPS) Terhadap Harga Saham Perusahaan yang Tergabung dalam Indeks LQ45 di Bursa Efek Indonesia Periode Tahun 2013-2015. Jurnal EMBA, 5(1), 105.

Filbert, R., \& Prasetya, W. (2020). Investasi Saham Ala Fundamentalis Dunia. Jakarta: Elex Media Komputindo.

Hana, K. F. (2018). Dialektika Hukum Trading Saham Syariah di Bursa Efek Indonesia. Tawazun: Journal of Sharia Economic Law, 1(2), 148-160. Retrieved from http://journal.stainkudus.ac.id/index.php/tawazun/index

Haq, M. R., Sari, D. P. F., \& Hana, K. F. (2020). Peran Sukuk Terhadap Pembangunan Infrastruktur. Al-Mutharahah, 17(1), 87-103. Retrieved from http://ojs.diniyah.ac.id/index.php/Al-Mutharahah

Husnan, S. (2015). Dasar-dasar Teori Portofolio dan Analisis Sekuritas. Yogyakarta: UPP STIM YKPN.

Kasmir. (2016). Analisis Laporan Keuangan. Jakarta: Rajawali Pers.

Rahardjo, S. (2006). Kiat Membangun Aset Kekayaan. Jakarta: Elex Media Komputindo.

Ramdhani, R. (2013). Pengaruh Return On Assets dan Debt To Equity Ratio Terhadap Harga Saham pada Institusi Finansial di Bursa Efek Indonesia. Journal The Winners, 14(1), 31.

Rini, S., Farrukhy, A. F., \& Hana, K. F. (2020). Komparasi Risk dan Return Saham dan Saham Syariah. ASSETS, 10(1), 83-97.

Saputro, D. (2019). Pengaruh Return on Assets, Earnings per Share dan Book Value per Share terhadap Harga Saham. Jurnal Samudra Ekonomi Dan Bisnis, 10(2), 126.

Sugiyono. (2014). Statistika Untuk Penelitian. Bandung: Alfabeta.

Sukamulja, S. (2019). Analisis Laporan Keuangan sebagai Dasar Pengambilan Keputusan Investasi. Yogyakarta: ANDI dengan BPFE.

Syamsuddin, L. (2011). Manajemen Keuangan Perusahaan: Konsep Aplikasi dalam Perencanaan, Pengawasan, dan Pengambilan Keputusan. Jakarta: Rajawali Pers.

Tejaningtyas, S. R. (2016). Analisis Pengaruh Rasio Profitabilitas Terhadap Harga Saham pada Perusahaan Real Estate dan Property yang Terdaftar di Bursa Efek Indonesia Tahun 2012-2014. JRAMB, 2(2), 148. 